\title{
ANALISIS ALIRAN UDARA FAN BLADE PADA MESIN CFM56-7B BOEING 737-800NG DENGAN COMPUTATIONAL FLUID DYNAMIC (CFD)
}

\author{
YAFID EFFENDI ${ }^{1}$, JAMALUDIN ${ }^{2}$, SARIFUDIN $^{3}$ \\ Program Studi Teknik Mesin, Fakultas Teknik, Universitas Muhammadiyah Tangerang \\ Jl. Perintis Kemerdekaan I/33 Cikokol-Tangerang \\ E-Mail : yafideffendi@yahoo.com
}

\begin{abstract}
ABSTRAK
Pesawat terbang merupakan transportasi yang sangat diminati oleh masyarakat, karena kenyamanan dan waktu penerbangan yang sangat singkat. Pada saat ini penguasaan teknologi rancang bangun di bidang kedirgantaraan sangatlah pesat contohnya saja bermunculan berbagai jenis pesawat terbang seperti Boeing series, Airbus Series, Bombardir Series, ATR Series, bahkan dalam negeri juga mempunyai pesawat tersendiri buatan PT Dirgantara Indonesia seperti CN (235,295,2235-200), NC212, Helikopter H21 Super Puma, N219, dan lain-lain. Aliran udara melewati fan blade pada pesawat terbang jenis BOEING 737-800NG dengan mesin CFM56-7B yang dianalisa menggunakan software CFD. Pada penelitian ini memfokuskan pengaruh ketinggian terhadap kecepatan, gaya dorong, dan gaya hambat pada aliran udara melewati fan blade dengan menggunakan software CFD. Metode yang digunakan dalam penelitian ini, pengumpulan data langsung pada objek yang di analisis pada software CFD. Berdasarkan simulasi pada CFD dapat disimpulkan bahwa Velocity $x$ dan pressure setelah melewati fan blade pada ketinggian 10.000 feet, masing-masing menghasilkan 157,057 $\mathrm{m} / \mathrm{s}$ dan $64801.10 \mathrm{pa}$. Sedangkan berdasarkan ketinggian 20.000 feet, masing-masing menghasilkan $199,797 \mathrm{~m} / \mathrm{s}$ dan 30619,11 Pa. Pola aliran udara yang dibelakang fan blade menghasilkan pola aliran udara laminar dan gaya dorong (thrust) dan gaya tahanan (drag) yang di hasilkan pada ketinggian 10.000 feet berturut-turut adalah 115120,442 N dan 12244,13N, dan pada ketinggian 20.000 feet adalah 134418,55 $N$ dan 15965,3.
\end{abstract}

Kata Kunci : Turbofan, CFD, kecepatan, tekanan, gaya dorong.

\begin{abstract}
Airplanes are transportation that is in great demand by the public, because of its convenience and very short flight times. At this time the mastery of engineering design technology in the aerospace sector is very fast, for example, various types of aircraft have emerged such as the Boeing series, Airbus Series, Bombardir Series, ATR Series, even domestically they also have their own aircraft made by PT Dirgantara Indonesia such as $C N$ (235,295,2235-200), NC212, H21 Super Puma Helicopter, N219, and others. The air flow through the fan blade on the BOEING 737-800NG aircraft with the CFM56-7B engine was analyzed using CFD software. This study focuses on the effect of altitude on speed, thrust, and drag on air flow through the fan blade using CFD software. The method used in this research, direct data collection on the object that is analyzed in CFD software. Based on the simulation on CFD, it can be concluded that Velocity $x$ and pressure after passing through the fan blade at an altitude of 10,000 feet, produce $157.057 \mathrm{~m} / \mathrm{s}$ and $64801.10 \mathrm{pa}$, respectively. Meanwhile, based on an altitude of 20,000 feet, each produces 199,797 m/s and $30619.11 \mathrm{~Pa}$. The airflow pattern behind the fan blade produces a laminar airflow pattern and the thrust and drag at an altitude of 10,000 feet are 115120,442 $\mathrm{N}$ and $12244.13 \mathrm{~N}$, and at an altitude of 20,000 feet, respectively. $134418.55 \mathrm{~N}$ and 15965.3.
\end{abstract}

Keywords: Turbofan, CFD, Velocity x, pressure, Thrust.

\section{PENDAhUluan}

Seiring dengan perkembangan teknologi pesawat terbang sangat mendominasi dari segi transportasi. Pada zaman sekarang mesin pesawat terbang menggunakan jenis turbin gas (Gas Turbine Engine) dan Mesin torak (piston engine), Mesin torak pada umumnya di gunakan pada pesawat yang kecil dan berjelajah jarak dekat sedangkan mesin Turbin gas pada umumnya digunakan pada pesawat terbang komersial maupun pesawat militer dan berjelajah jarak jauh. Mesin turbin gas ini di bedakan lagi menjadi empat jenis yaitu mesin turbofan, mesin turboprop, mesin turboshaft dan mesin turbojet. Di mesin turbofan kompressor di bagi menjadi dua yaitu kompressor tekanan tinggi (High Pressure Compressor) dan kompressor tekanan rendah (Low Pressure Compressor). Dibagian paling depan di mesin turbofan ada sebuah baling-baling yang berfungsi untuk menarik udara masuk ke mesin dan baling-baling disebut Fan Blade. Fan Blade ini bertindak sebagai Kompressor tekanan rendah (Low Pressure Compressor). Pada 
saat ini Fan Blade mempunyai desain yang berbedabeda mungkin itu berbeda dari bentuk sudutnya, bentuk airfoilnya, bentuk permukaannya maupun yang lainnya, maka terjadilah perbedaan dari segi pola aliran udara, velocity (kecepatan) udara maupun tekanan (pressure) udara dan gaya dorong (trusth) yang dihasilkan. Dengan aplikasi Computational fluid dynamic (CFD) fan blade tersebut dapat di simulasi sehingga dapat di ketahui perbedaaan dari dua buah fan blade yang berbeda. Dalam penelitian ini mengenal aliran udara $f a n$ blade pada mesin CFM 56 -7B-72 dengan computational fluid dynamic (CFD).

\section{METODOLOGI PENELITIAN}

Metode penelitian ini menggukan metode numeric 2D dan 3D dengan bantuan software computer yaitu CFD solidword dan menggunakan rumus gaya dorong, gaya tahanan, dan angka reynold.

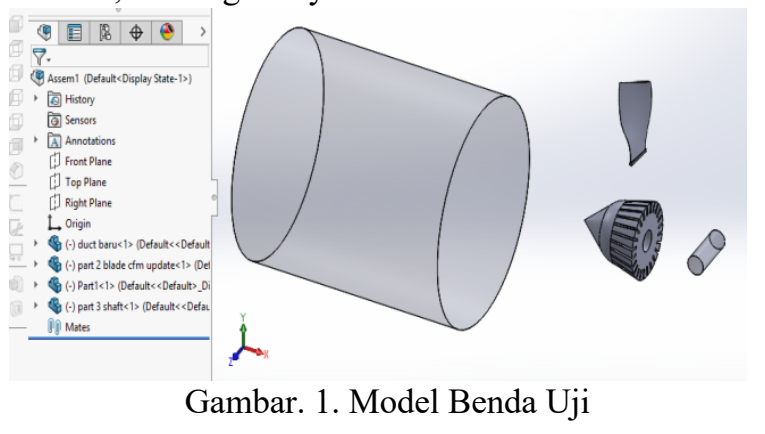

\section{A. Tahap Pre-processing}

Pada tahap ini benda di gambar pada solidwork meliputi 2D dan 3D.

Gambar. 2. Pemodelan di solidwork

\section{B. Tahap Processing}

Pada tahap ini parameter pemodelan serta kondisi yang telah di tetapkan pada saat pre-processing akan di hitung oleh sofware komputer dan jika pengujian berhasil, akan berlanjut ke proses past-processing.

\section{Tahap Past-processing}

Pada tahap ini hasil dari simulasi solidwork akan muncul berupa gambar, data, grafik, dan simulasi berupa video.

D. Tahap Perhitungan

Pada tahap ini penulis akan mencari gaya dorong fan blade, gaya tahanan, dan jenis aliran dengan rumus angka reynold.

\section{Gaya dorong fan blade:}

$$
\begin{aligned}
& F_{0, F}=\left(\rho A_{F} v_{F}\right) \mathcal{V}_{F}=\rho A_{F} v_{F}^{2} \\
& \mathrm{~F}=\text { gaya dorong }(\mathrm{N}) \\
& \rho=\text { density }\left(\mathrm{kg} / \mathrm{m}^{3}\right) \\
& \mathrm{A}=\text { luas penampang }\left(\mathrm{m}^{2}\right) \\
& v_{F}=\text { kecepatan udara di belakang fan blade }(\mathrm{m} / \mathrm{s})
\end{aligned}
$$

Gaya tahanan satu fan blade :

$$
\begin{aligned}
& C d=\frac{d}{\frac{1}{2} \rho c C_{R}^{2}} \\
& C d=\text { koefisien tahanan } \\
& \mathrm{d}=\text { gaya tahanan }(\mathrm{N}) \\
& \rho=\text { density }\left(\mathrm{kg} / \mathrm{m}^{3}\right) \\
& \mathrm{c}=\text { luas penampang }\left(\mathrm{m}^{2}\right) \\
& C_{R}=\text { kecepatan udara dilihat fan blade }(\mathrm{m} / \mathrm{s})
\end{aligned}
$$
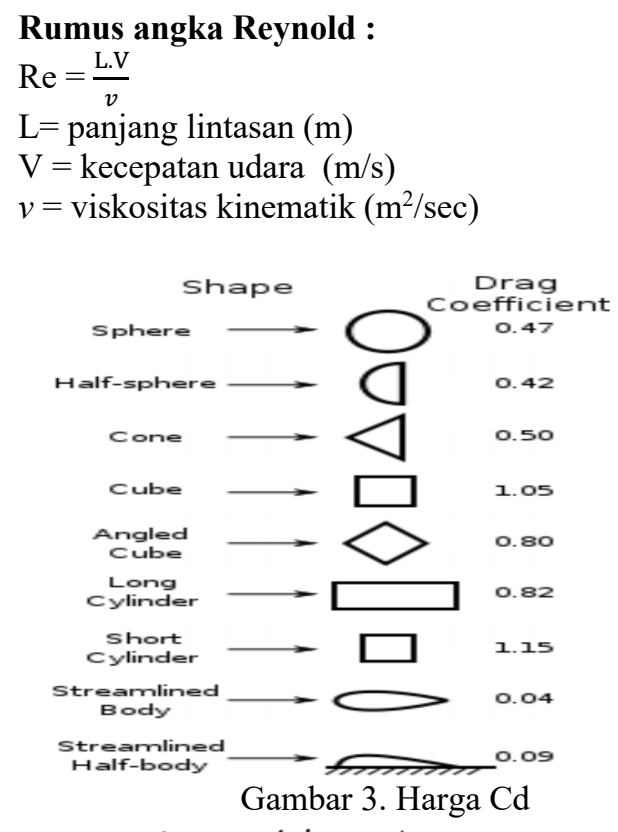

Untuk permukaan yang halus merata

$$
\operatorname{Re}_{e}=4.85 \times 10^{5}
$$

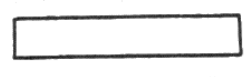

Untuk irisan sayap di atmosfir

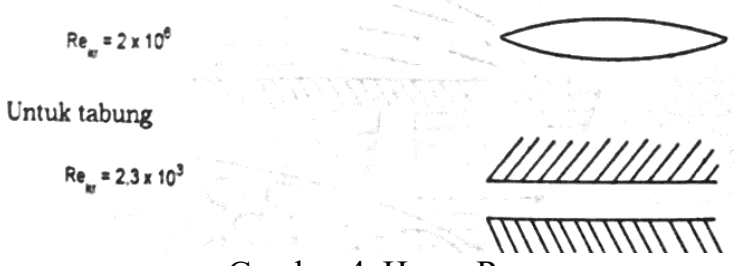

Gambar 4. Harga Re

\section{HASIL DAN PEMBAHASAN}

\section{Velocity $\mathrm{x}$ pada 10.000 feet}

Gambar 5 menunjukkan distribusi aliran kecepatan udara pada fan blade menuju kearah $\mathrm{x}$, karena benda fan blade kearah x. Awal mula kecepatan udara diluar hasil dari input yang sudah ditentukan dengan warna kuning $126.75 \mathrm{~m} / \mathrm{s}$. Fan 
blade berputar dan aliran kecepatan udara terhisap oleh fan blade, lalu kecepatan udara sudah mulai meningkat mendekati fan blade dengan warna merah setelah itu, terjadi stagnasi point pada fan blade sehingga kecepatan udara menjadi nol. Kecepatan udara melewati (output) fan blade menghasilkan warna merah yang tinggi dengan kecepatan tinggi yang maksimal yaitu $164.762 \mathrm{~m} / \mathrm{s}$ setelah itu, output yang keluar warna merah semakin lama akan berkurang karena jarak kecepatan aliran udara menjauh dari fan blade., hasil keluar (output) kecepatan udara dari fan blade lebih besar dari pada input yang masuk ke fan blade.

Pada kecepatan udara ditengah dengan warna hijau mendekati spinner. Menandakan kecepatan udara menurun, karena terhambat dengan spinner dan kecepatan udara melewati (output) spinner menghasilkan warna biru menandakan kecepatan udara menjadi hampa akibat terhambatnya spinner sehingga aliran ditengah tidak ada kenaikan kecepatan udara.

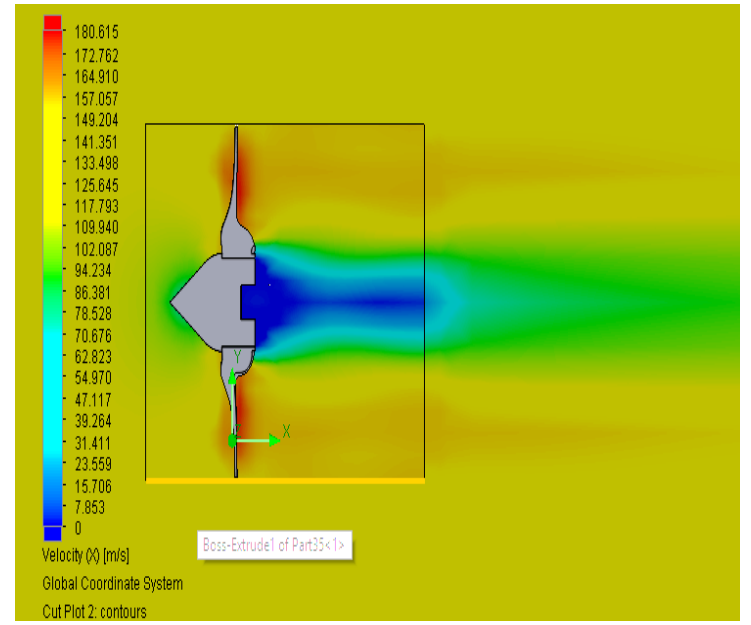

Gambar. 5. Velocity X pada 10.000 feet

\section{Velocity x pada 20.000 feet}

Pada ketinggian 20.000 feet bisa kita lihat pada Gambar 6, kecepatan aliran udara mengalami kenaikan ketika mendekati fan blade yaitu 199.797 $\mathrm{m} / \mathrm{s}$ dan setalah melewati fan blade kecepatan udara maksimal adalah $239.757 \mathrm{~m} / \mathrm{s}$ dari input kecepatan udara $164.1 \mathrm{~m} / \mathrm{s}$, ini membuat kenaikan kecepatan udara sampai $65.667 \mathrm{~m} / \mathrm{s}$. Kenaikan kecepatan udara ini bisa di akibat oleh kerapatan udara dan putaran fan blade itu sendiri. Di depan spinner terjadi stagnasi point yaitu dimana aliran udara terbentur di spinner membuat kecepatan udara menjadi berkurang, disitu juga terjadinya terbelahnya lapisan-lapisan udara.

Pada di bekakang fan blade kecepatan aliran udara berwarna hijau itu akan di gunakan untuk masuk ke compressor untuk dijadikan udara dan fuel yang di bakar di ruang pembakaran. Dan di belakang spinner warna biru itu adalah kecepatan udara $0 \mathrm{~m} / \mathrm{s}$ karena di situ udara menjadi hampakarena di halangi oleh spinner.

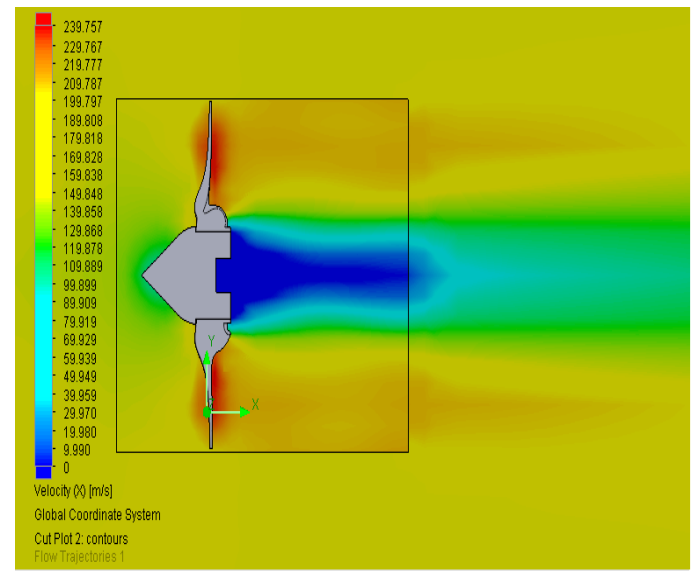

Gambar. 6. Velocity x pada 20.000 feet

\section{Pressure Fan Blade Pada $\mathbf{1 0 . 0 0 0}$ feet}

Gambar 7 memperlihatkan distribusi aliran udara pressure pada fan blade menuju kearah $\mathrm{x}$, karena benda fan blade kearah x. Awal mula aliran pressure udara diluar hasil dari input yang sudah ditentukan dengan warna kuning tua dengan angka 66879.14 pa, lalu fan blade berputar sehingga pressure input yang mendekati fan blade mengalami penurunan dengan warna hijau dengan angka 64801.10 pa setelah itu, pada saat di tengah fan blade pressure berwarna biru muda dengan angka 61206.78 pa.

Pada aliran pressure udara pada bagian tengah bermula pressure input bewarna kuning tua. Mendekati spinner pressure udara menjadi tinggi dengan warna merah dengan angka 71390.68 pa karena terhambat dengan spinner setelah itu, keluar (output) dengan warna biru tua dengan angka 57612.56 pa dari spinner terjadi penurunan pressure karena tidak ada distribusi pressure udara sehingga aliran udara dibagian spinner menjadi hampa dan tidak ada aliran pressure.

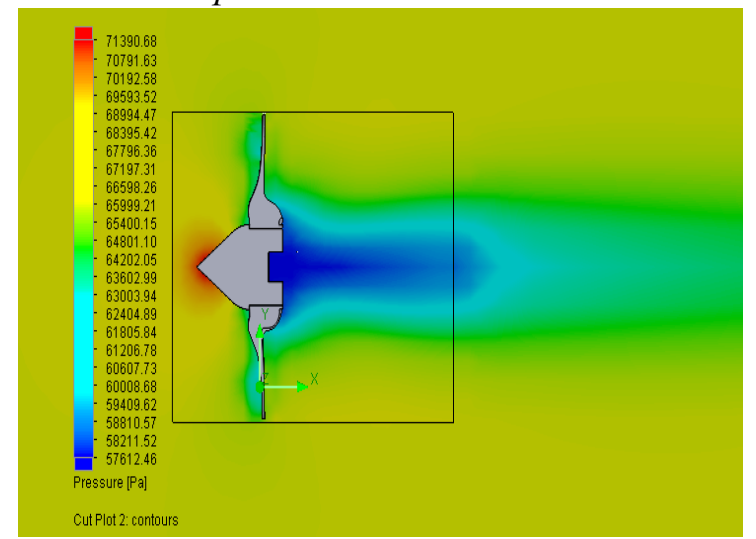

Gambar 7. Pressure pada 10.000 feet 


\section{Pressure Fan Blade Pada 20.000 feet}

Pressure udara pada ketinggian 20.000 feet bisa kita lihat pada Gambar 8. Di sini kita mengambil kesimpulan bahwa pressure udara di belakang fan blade adalah 30619.11 Pa yang berwarna hijau. Pada di tengah-tengah fan blade pressure udara sangat rendah yaitu 27007.54 pa itu di karena kan kecepatan putar dari fan blade membuat kecepatan udara semakin tinggi sehigga pressure udara nya menjadi rendah juga, terihat warna biru muda pada tengahtengah fan blade. Karena bentuk dari fan blade adalah airfoil, ketika aliran udara dibelah oleh fan blade itu membuat airan udara yang menempel pada permukaan fan balde kecepatannya jadi cepat daripada ketika sebelum berada di permukaan fan blade, sama seperti hukum airfoil pada umumnya. Di depan ujung spinner terjadi stagnasi, pressure udara di titik ini menjadi sangat tinggi karena kecepatan udara sangat rendah yang di akibatkan oleh spinner tersebut. Stagnasi adalah dimana lapisan-lapinsan aliran udara terbelah. Di belakang spinner terjadi hampa udara, di bagian ini kecepatan udaranya $0 \mathrm{~m} / \mathrm{s}$, dengan kecepatan udara tersebut bukan berarti tekanan udaranya menjadi tinggi, yang terjadi sebaliknya adalah tekanan udara rendah, tekanan rendah ini disebabkan oleh karena daerah tersebut komposisi atau volume udara nya sangat rendah atau kerapatan udaranya sangat rendah karena aliran udara terhalang oleh spinner dan aliran udara yang di hasilkan oleh fan blade hanya melaju kebelakang dengan kecepatan tinggi.

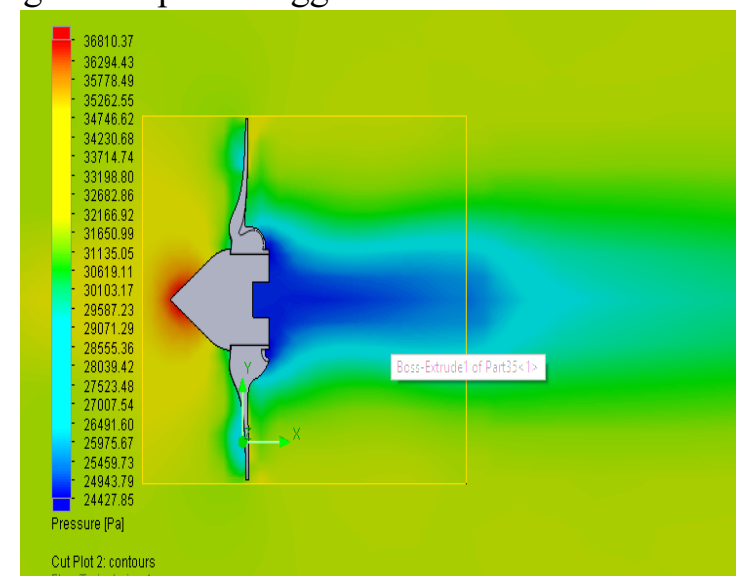

Gambar 8. Pressure pada 20.000 feet

\section{Pola Aliran Udara Fan Blade Ketinggian 10.000 Feet}

Pada Gambar 9. memperlihatkan karateristik aliran udara adanya aliran udara laminar dan turbulen. Bisa dilihat garis-garis di atas adalah lapisan-lapisan aliran udara, di depan spinner terjadi stagnasi dimana lapisan-lapisan aliran udara terbelah oleh spinner. Di bagian fan blade terlihat jelas bahwa garis-garis lapisan udara terputus pada saat mendekati fan blade dan setelah melewati fan blade terjadi lapisan-lapisan aliran udara baru. Aliran udara yang dihasilkan oleh fan blade dikatakan laminar karena aliran udaranya bergerak kebelakang dengan perubahan kecepatan yang tidak naik turun atau disimpulkan penurunan kecepatannya konstant.

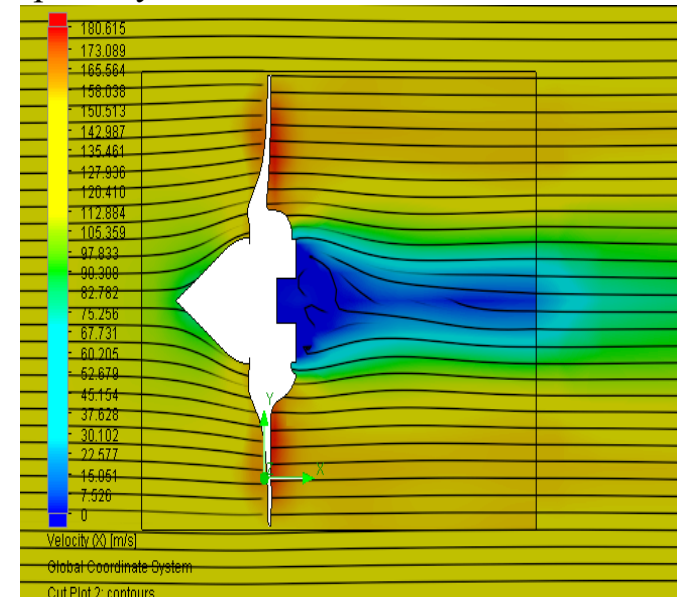

Gambar 9. Pola Aliran Udara Fan Blade pada 10.000 feet

\section{a) Angka Reynold Pada Puncak Fan Blade}

Sekarang penulis akan mencoba menghitung bilangan Reynold pada permukaan daun fan blade. Karena penampang fan blade itu airfoil maka bisa di nyatakan bahwa aliran turbulen akan muncul pada bilangan Re di atas $2 \times 10^{6}$ (lihat gambar 4).

Semua parameter dari rumus angka renold di ambil dari kondisi udara yang dipengaruhi daya hisap oleh fan blade. Jadi diameter (D) atau panjang lintasan (L) di ambil panjang chord line di puncak yaitu 0.267 $\mathrm{m}$, density $(\rho)$ di ambil dari suhu udara-6,09 C (267,06 $\mathrm{K})$ pada lampiran 3 dicari dengan rumus interpolasi, viscosity $(\mu)$ dari tabel lampiran pada suhu $-6,09$ C (suhu udara di depan blade puncak) dicari dengan perbandingan interpolasi pada tabel lampiran 8, dan kecepatan udara (V) di ambil dari kecepatan udara yang akan masuk di puncak fan blade yaitu 142,987 $\mathrm{m} / \mathrm{s}$.

Interpolasi viscosity $(\mu)$ pada suhu $-6,09 \mathrm{C}$ Jadi angka Reynold nya $=\frac{\rho \mathrm{V} \mathrm{L}}{\mu}$

$$
\begin{aligned}
\operatorname{Re} & =\frac{0,7308 \frac{\mathrm{kg}}{\mathrm{m}^{3}} \times 142,987 \frac{\mathrm{m}}{\mathrm{s}} \times 0.267 \mathrm{~m}}{1,7 \times 10-5 \mathrm{~N} \mathrm{~s} / \mathrm{m}^{2}} \\
\operatorname{Re} & =1641184
\end{aligned}
$$

Karena jumlah Re pada puncak fan blade lebih kecil dari $2 \times 10^{6}$, maka bisa dipastikan bahwa aliran udara pada puncak fan blade adalah aliran laminar. 


\section{b) Angka Reynold Pada Tengah Fan Blade}

Sekarang penulis akan menghitung jenis aliran udara pada tengah-tengah fan blade (seluruh parameter rumus parameter angka Reynold fokus pada tengah fan blade.

Diketahui : suhu udara mendekati tengah fan blade adalah $-8(265,15) \mathrm{K}$ pada lampiran 1 .

Interpolasi density $(\rho)$ pada suhu $-8 \mathrm{C}$

Nilai density $(\rho)=0,7156-\frac{0,8}{2} \times(0,7156-0,6932)=$ $0,706 \frac{\mathrm{kg}}{\mathrm{m}^{3}}$

Jadi nilai viscosity $(\mu)=1,71 \times 10^{-5}$

$\mathrm{L}=0.267 \mathrm{~m}$ (Panjang chord line sama dengan puncak karena penulis membuat panjang fan blade dari tengah sampai puncak mempunyai panjang chord line yang sama)

$$
\begin{aligned}
\mathrm{V}= & 150,513 \mathrm{~m} / \mathrm{s} \\
\operatorname{Re} & =\frac{\rho \mathrm{VL}}{\mu} \\
\operatorname{Re} & =\frac{0,706 \frac{\mathrm{kg}}{\mathrm{m}^{3}} \times 150,987 \frac{\mathrm{m}}{\mathrm{s}} \times 0.267 \mathrm{~m}}{1.71 \times 10^{-5} \mathrm{~N} \mathrm{~s} / \mathrm{m}^{2}} \\
\operatorname{Re} & =1664400
\end{aligned}
$$

Sama hal nya dengan bahwa aliran udara pada tengah-tengah fan blade adalah aliran laminar.

\section{c) Angka Reynold Pada Puncak Fan Blade}

Sekarang penulis akan menghitung jenis aliran udara pada pangkal/root fan blade (seluruh parameter rumus parameter angka Reynold fokus pada pangkal/root fan blade.

Diketahui : di lampiran 1 di ketahui suhu udara mendekati root/pangkal fan blade adalah -8 $(265,15)$ $\mathrm{K}$. Maka harga density dan viscosity nya sama dengan yang di tengah fan blade.

$\mathrm{P}=0,706 \frac{\mathrm{kg}}{\mathrm{m}^{3}}$

$\mathrm{L}=0.235 \mathrm{~m}$

$\mu=1.71 \times 10^{-5} \mathrm{~N} \mathrm{~s} / \mathrm{m}^{2}$ (pada suhu $-8 \mathrm{C}$ )

$\mathrm{V}=141,351 \mathrm{~m} / \mathrm{s}$

$\operatorname{Re}=\frac{\rho \mathrm{VL}}{\mu}$

$\operatorname{Re}=\frac{0.706 \frac{\mathrm{kg}}{\mathrm{m}^{3}} \times 141,351 \frac{\mathrm{m}}{\mathrm{s}} \times 0.235 \mathrm{~m}}{1.71 \times 10^{-5} \mathrm{~N} \mathrm{~s} / \mathrm{m}^{2}}$

$\operatorname{Re}=1371435,35$

Dengan angka Reynold di atas bisa di simpulkan bahwa aliran udara yang di hasilkan pada pangkal (root) adalah aliran laminar juga.

\section{Pola Aliran Udara Fan Blade Ketinggian 20.000 Feet}

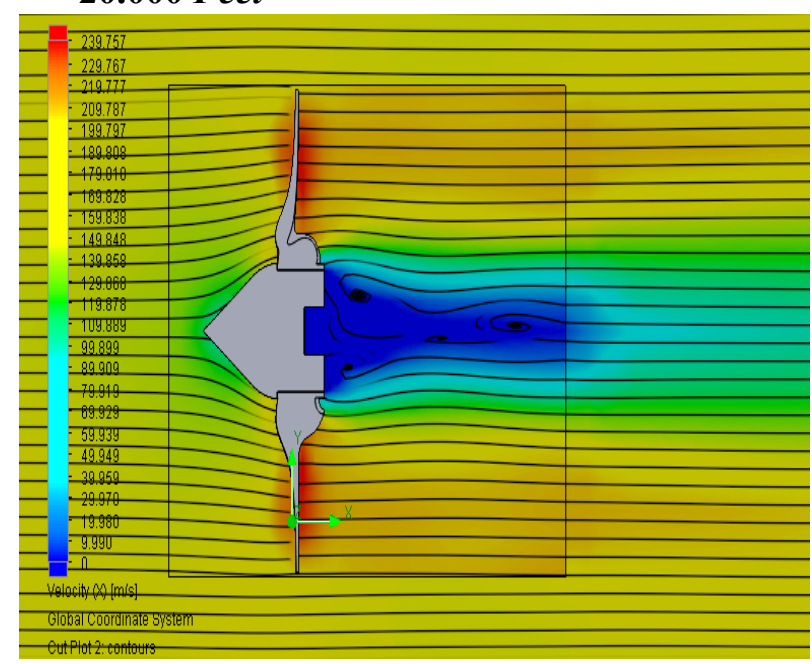

Gambar 10. Pola Aliran Udara Fan Blade pada 20.000 feet

Sedangkan pada ketinggian 20.000 feet Pada Gambar 10. menunjukkan karateristik aliran udara adanya aliran udara laminar dan turbulen. Tidak jauh beda pada ketinggian 10.000 feet aliran udara yang dihasilkan oleh fan blade adalah laminar karena aliran udara semakin kebelakang alirannya tetap sejajar pada lintasan sebelumnya dan mengalami penurunan kecepatan secara konstan.

\section{a) Angka Reynold Pada Puncak Fan Blade}

suhu udara mendekati tengah fan blade adalah -8 $(265,15) \mathrm{K}$ pada lampiran 2.

Interpolasi density $(\rho)$ pada suhu $-26,19 \mathrm{C}(246,96 \mathrm{~K})$ pada lempiran 2.

density $(\rho)=0,5328-\frac{0,41}{2} \times(0,5328-0,5150)=0,529$

$\frac{\mathrm{kg}}{\mathrm{m}^{3}}$

Interpolasi viscosity $(\mu)$ pada suhu $-26,19 \mathrm{C}$ viscosity $(\mu)$

$\operatorname{Re}=1590183$

Karena jumlah Re pada puncak fan blade lebih kecil dari $2 \times 10^{6}$, maka bisa dipastikan bahwa aliran udara pada puncak fan blade adalah aliran laminar.

\section{b) Angka Reynold Pada Tengah Fan Blade}

Sekarang penulis akan menghitung jenis aliran udara pada tengah-tengah fan blade (seluruh parameter rumus parameter angka Reynold fokus pada tengah fan blade).

suhu udara mendekati tengah fan blade adalah $29,82 \mathrm{C}(243,33) \mathrm{K}$

$$
\mathrm{L}=0.267 \mathrm{~m}
$$


$\mathrm{V}=189,808 \mathrm{~m} / \mathrm{s}$

Interpolasi density $(\rho)$ pada suhu $-29,82 \mathrm{C}(243,33)$ $\mathrm{K}$

density $(\rho)=0,4976-\frac{0,78}{2} \times(0,4976-0,4806)=0,491$

$\frac{\mathrm{kg}}{\mathrm{m}^{3}}$

Interpolasi viscosity $(\mu)$ pada suhu $-29,82 \mathrm{C}$ pada lempiran 5

$\operatorname{viscosity}(\mu)=1,61 \times 10^{-5}-\frac{-0.18}{-10} \times\left(1,61 \times 10^{-5}-1,56\right.$ $\mathrm{x} 10^{-5}$ )

$=1,61 \times 10^{-5}-0,09 \times 10^{-7}=1,609 \times 10^{-5}$

$$
\operatorname{Re}=1458525
$$

Sama hal nya dengan bahwa aliran udara pada tengah-tengah fan blade adalah aliran laminar.

c) Angka Reynold Pada Pangkal/root Fan Blade

Sekarang penulis akan menghitung jenis aliran udara pada pangkal/root fan blade (seluruh parameter rumus parameter angka Reynold fokus pada pangkal/root fan blade.

suhu udara sama dengan di tengah fan blade yaitu $29,82 \mathrm{C}(243,33) \mathrm{K}$.

$\mathrm{L}=0.235 \mathrm{~m}$

$$
\rho=0.4911 \mathrm{~kg} / \mathrm{m}^{3}
$$

$\mu=1.609 \times 10^{-5} \mathrm{~N} \mathrm{~s} / \mathrm{m}^{2}$

$\mathrm{V}=169,828 \mathrm{~m} / \mathrm{s}$

$\operatorname{Re}=\frac{\rho \mathrm{VL}}{\mu}$

$\operatorname{Re}=\frac{0.4911 \frac{\mathrm{kg}}{\mathrm{m}^{3}} \times 169,828 \frac{\mathrm{m}}{\mathrm{s}} \times 0.235 \mathrm{~m}}{1.609 \times 10^{-5} \mathrm{~N} \mathrm{~s} / \mathrm{m}^{2}}$

$\operatorname{Re}=1218122,7$

Dengan angka Reynold di atas bisa di simpulkan bahwa aliran udara yang di hasilkan pada pangkal (root) adalah aliran laminar juga.

\section{Gaya Dorong (thrust) Fan Blade pada 10.000 feet}

Pada bagian ini penulis akan mencari gaya dorong (trusth) yang di hasilkan oleh Fan Blade menggunakan data-data dari hasil CFD dengan rumus gaya dorong pada masing-masing ketinggian.

Dibagian ini penulis akan mencari gaya dorong fan blade dengan data kecepatan udara di belakang fan blade( $v_{F}^{2}$ ) di ambil dari Gambar 9, density udara $(\rho)$ pada lampiran dan luas penampang Fan Blade $(A F)$ di ambil dari dengan menghitung seluruh luas fan blade.

Diketahui : rumus gaya dorong fan blade

--> $F F=\rho A F v_{F}^{2}$

$\rho$ (density udara $)=0.7385 \frac{\mathrm{kg}}{\mathrm{m}^{3}}$

$A F$ (luas penampang Fan Blade $)=6.32 \mathrm{~m}^{2}$
$v_{F}^{2}$ (kecepatan udara di belakang fan blade) $=157.057 \mathrm{~m} / \mathrm{s}$

Jawaban : $\quad F F=\rho A F v_{F}^{2}$

$$
\begin{aligned}
& F F=0,7385 \frac{\mathrm{kg}}{\mathrm{m}^{3}} \times 6.32 \mathrm{~m}^{2} \mathrm{x} \\
& (157.057 \mathrm{~m} / \mathrm{s})^{2} \\
& F F=4,667 \frac{\mathrm{kg}}{\mathrm{m}} \times 24666,9(\mathrm{~m} / \mathrm{s})^{2} \\
& F F=115120,442 \mathrm{~kg} \frac{\mathrm{m}}{\mathrm{s}^{2}} \\
& \quad=115120,442 \text { Newton }
\end{aligned}
$$

\section{Gaya Dorong (thrust) Fan Blade pada 20.000 feet}

Dibagian ini penulis akan mencari gaya dorong fan blade pada ketinggian 20.000 feet dengan data kecepatan udara di belakang fan blade $\left(v_{F}^{2}\right)$ di ambil dari Gambar 10, density udara $(\rho)$ pada lampiran dan luas penampang Fan Blade $(A F)$ di ambil dari dengan menghitung seluruh luas fan blade.

Diketahui : rumus gaya dorong fan blade--> FF $=\rho A F v_{F}^{2}$

$\rho$ (density udara $)=0.5328 \frac{\mathrm{kg}}{\mathrm{m}^{3}}$

$A F$ (luas penampang Fan Blade) $=6.32 \mathrm{~m}^{2}$

$v_{F}^{2}$ (kecepatan udara di belakang fan blade $)=199,797$ $\mathrm{m} / \mathrm{s}$

$$
\begin{aligned}
& \text { Jawaban : } \quad F F=\rho A F v_{F}^{2} \\
& F F=0,5328 \frac{\mathrm{kg}}{\mathrm{m}^{3}} \times 6.32 \mathrm{~m}^{2} \times(199,797 \mathrm{~m} / \mathrm{s})^{2} \\
& F F=3,367 \frac{\mathrm{kg}}{\mathrm{m}} \times 39918,84 \mathrm{~m}^{2} / \mathrm{s}^{2} \\
& F F=134418,55 \mathrm{~kg} \frac{\mathrm{m}}{\mathrm{s}^{2}}=134418,55 \text { Newton }
\end{aligned}
$$

\section{Gaya Tanahan (drag) Fan Blade pada 10.000 feet}

Pada bagian ini penulis akan mencari gaya tahanan (drag) yang di hasilkan oleh fan blade menggunakan data-data dari hasil CFD dengan rumus gaya dorong pada masing-masing ketinggian

Dibagian ini penulis akan mencari gaya tahanan fan blade pada ketinggian 10.000 feet dengan luas penampang fan blade (c), density udara $(\rho)$ pada lampiran dan drag coefficient $\left(C_{d}\right)$ terdapat pada Lampiran.

rumus gaya tahanan satu daun fan blade-->

$d=\frac{1}{2} C_{d} \rho c c_{R}^{2}$

$\rho$ (density udara $)=0.7385 \frac{\mathrm{kg}}{\mathrm{m}^{3}}$

$C_{d}=0.12$

$c$ (luas penampang satu daun fan blade) $=0.263 \mathrm{~m}^{2}$

$C_{R}=\frac{C_{0}^{\prime}}{\sin \phi}=\frac{C_{0}(1+a)}{\sin \phi}$ dan

$\tan \phi$ (sudut maju) $=\frac{C_{0}^{\prime}}{\omega^{\prime} r}=\frac{C_{0}(1+a)}{(1-a \omega) \omega r}=\frac{J(1+a)}{\pi x(1-a \omega)}$ 
$n=2587,5 \mathrm{rpm}=43,125$ rotation per second

$C_{0}=126.75 \mathrm{~m} / \mathrm{s}$

$R=0.528 m, \mathrm{D}=1,056 \mathrm{~m}$

$J=\frac{C 0}{n D}=\frac{126.75 \mathrm{~m} / \mathrm{s}}{43,125 \mathrm{rps} 1,056 \mathrm{~m}}=2,78$

$\pi=3,14$

$x=1$

karena pesawat terbang mendatar (cruise) dan pola aliran udara yang masuk ke fan blade adalah laminar maka untuk harga a (factor aliran masuk) dan $a \omega$ (factor aliran masuk berputar) kita samakan dengan 0 , karena harga 7actor aliran tersebut sangat kecil.

$$
\begin{aligned}
\tan \phi & =\frac{J(1+a)}{\pi x(1-a \omega)} \\
\tan \phi & =\frac{2,78(1+0)}{3,14.1(1-0)}=\frac{2,78}{3,14} \\
\tan \phi & =0,885 \\
\phi & =41.5 \text { degree }
\end{aligned}
$$

dan untuk harga $\sin \phi, \sin 41.5$ degree $=0.662$

dan harga $C_{R}, C_{R}=\frac{C_{0}(1+a)}{\sin \phi}=\frac{126.75 \mathrm{~m} / \mathrm{s}}{0.662}=191,46$ $\mathrm{m} / \mathrm{s}$

jadi harga tahanan satu fan blade,

$$
\begin{aligned}
& d=\frac{1}{2} C_{d} \rho c c_{R}^{2} \\
& d=\frac{1}{2} 0,12 \times 0.7385 \frac{\mathrm{kg}}{\mathrm{m}^{3}} \times 0.263 \mathrm{~m}^{2} \times \\
& (191,46 \mathrm{~m} / \mathrm{s})^{2} \\
& d=\frac{1}{2} 0,0233 \frac{\mathrm{kg}}{\mathrm{m}} \times 36657 \mathrm{~m}^{2} / \mathrm{s}^{2} \\
& d=\frac{1}{2} \times 854,36 \mathrm{~kg} \mathrm{~m} / \mathrm{s}^{2} \\
& d=427,2 \mathrm{~N}
\end{aligned}
$$

Gaya tahanan $(d) 427,2 \mathrm{~N}$ adalah gaya tahanan hanya satu daun fan blade, jika sebuah mesin CFM56-7B memiliki 24 fan blade, maka gaya tahanan 24 daun fan blade adalah :

$$
\begin{aligned}
\mathrm{F}_{\mathrm{d}} & =d \times 24 \\
\mathrm{~F}_{\mathrm{d}} & =427,2 \times 24 \\
& =10252,4 \mathrm{~N}
\end{aligned}
$$

\section{a. Gaya Tahanan $\left(S_{d}\right)$ Spinner Pada 10.000 feet}

Dibagian ini penulis akan mencari gaya tahanan fan blade pada ketinggian 10.000 feet dengan luas penampang spinner (A), density udara $(\rho)$ pada lampiran dan drag coefficient $\left(C_{d}\right)$ untuk bentuk benda seperti spinner terdapat pada gambar 3.

rumus gaya tahanan fan blade; $S_{d}=\frac{1}{2} C_{d} \rho A c_{o}^{2}$

$$
\begin{aligned}
& \rho(\text { density udara })=0.7385 \frac{\mathrm{kg}}{\mathrm{m}^{3}} \\
& C_{d}=0.5 \\
& A(\text { luas penampang Spinner })=0.6715 \mathrm{~m}^{2} \\
& C_{0}=126.75 \mathrm{~m} / \mathrm{s}
\end{aligned}
$$

jadi harga tahanan spinner,

$$
\begin{aligned}
& S_{d}=\frac{1}{2} C_{d} \rho A c_{o}^{2} \\
& S_{d}=\frac{1}{2} \times 0.5 \times 0.7385 \frac{\mathrm{kg}}{\mathrm{m}^{3}} 0.6715 \mathrm{~m}^{2} \mathrm{x} \\
& (126.75 \mathrm{~m} / \mathrm{s})^{2} \\
& S_{d}=\frac{1}{2} \times 0,248 \frac{\mathrm{kg}}{\mathrm{m}} \times 16065,5 \mathrm{~m}^{2} / \mathrm{s}^{2} \\
& S_{d}=1991,7 \mathrm{~N}
\end{aligned}
$$

Jadi gaya tahanan spinner pada ketinggian 10.000 feet adalah $1991,7 \mathrm{~N}$.

gaya tahanan $\left(F_{D}\right)$ fan blade pada ketinggian 10.000 feet adalah

$$
\begin{aligned}
& F_{D}=F_{d}+S_{d} \\
& F_{D}=10252,4 \mathrm{~N}+1991,7 \mathrm{~N} \\
& F_{D}=12244,13 \mathrm{~N}
\end{aligned}
$$

\section{Gaya Tahanan (drag) Fan Blade pada 20.000 feet}

Dibagian ini hampir sama cara nya seperti bagian 9, penulis akan mencari gaya tahanan fan blade pada ketinggian 20.000 feet dengan luas penampang fan blade (C), density udara $(\rho)$ pada lampiran dan drag coefficient $\left(C_{d}\right)$ terdapat pada lampiran.

gaya tahanan satu daun fan blade $\rightarrow d=$ $\frac{1}{2} C_{d} \rho c c_{R}^{2}$

$\rho($ density udara $)=0.5328 \frac{\mathrm{kg}}{\mathrm{m}^{3}}$

$C_{d}=0.12$

$c$ (luas penampang satu daun fan blade $)=$ $0.263 \mathrm{~m}^{2}$

$$
\begin{aligned}
& C_{R}=\frac{C_{0}^{\prime}}{\sin \phi}=\frac{C_{0}(1+a)}{\sin \phi} \text { dan } \\
& \tan \phi \quad \text { (sudut maju) }=\frac{C_{0}^{\prime}}{\omega^{\prime} r}=\frac{C_{0}(1+a)}{(1-a \omega) \omega r} \\
& =\frac{J(1+a)}{\pi x(1-a \omega)} \\
& n=3622,5 \mathrm{rpm}=60,375 \text { rotation per } \\
& \text { second } \\
& C_{0}=164,1 \mathrm{~m} / \mathrm{s} \\
& R=0.528 \mathrm{~m}, \mathrm{D}=1,056 \mathrm{~m} \\
& J=\frac{C 0}{n D}=\frac{164.1 \mathrm{~m} / \mathrm{s}}{60,375 \mathrm{rps} 1,056 \mathrm{~m}}=2,57 \\
& \pi=3,14 \\
& x=1
\end{aligned}
$$

karena pesawat terbang mendatar (cruise) dan pola aliran udara yang masuk ke fan blade adalah laminar maka untuk harga a (factor aliran masuk) dan $a \omega$ (factor aliran masuk berputar) kita samakan dengan 0 , karena harga 7actor aliran tersebut sangat kecil.

$$
\begin{aligned}
\tan \phi & =\frac{J(1+a)}{\pi x(1-a \omega)} \\
\tan \phi & =\frac{2,57(1+0)}{3,14 \cdot 1(1-0)}=\frac{2,57}{3,14} \\
\tan \phi & =0,818
\end{aligned}
$$




$$
\phi=39.3 \text { degree }
$$

Maka untuk harga $\sin \phi, \sin 39.3$ degree $=0.633$ dan harga $C_{R}, C_{R}=\frac{C_{0}(1+a)}{\sin \phi}=\frac{164.1 \mathrm{~m} / \mathrm{s}}{0.633}=259,2 \mathrm{~m} / \mathrm{s}$ jadi harga tahanan satu daun fan blade,

$$
\begin{aligned}
& d=\frac{1}{2} C_{d} \rho c c_{R}^{2} \\
& d=\frac{1}{2} 0,12 \times 0.5328 \frac{\mathrm{kg}}{\mathrm{m}^{3}} \times 0.263 \mathrm{~m}^{2} \times \\
& (259,2 \mathrm{~m} / \mathrm{s})^{2} \\
& d=\frac{1}{2} 0,0168 \frac{\mathrm{kg}}{\mathrm{m}} \times 67184,64 \mathrm{~m}^{2} / \mathrm{s}^{2} \\
& d=\frac{1}{2} \times 1129,7 \mathrm{~kg} \mathrm{~m} / \mathrm{s}^{2} \\
& d=564,86 \mathrm{~N}
\end{aligned}
$$

Gaya tahanan (d) 564,86 N adalah gaya tahanan hanya satu daun fan blade, jika sebuah mesin CFM56-7B memilLiki 24 fan blade, maka gaya tahanan 24 daun fan blade adalah :

$$
\begin{aligned}
& \mathrm{F}_{\mathrm{d}}=d \times 24 \\
& \mathrm{~F}_{\mathrm{d}}=564,86 \mathrm{~N} \mathrm{x24} \\
& \mathrm{F}_{\mathrm{d}}=13556,65 \mathrm{~N}
\end{aligned}
$$

\section{a. Gaya Tahanan $\left(S_{d}\right)$ Spinner Pada 20.000 feet}

Dibagian ini hampir sama dengan bagian 4.4.2, penulis akan mencari gaya tahanan spinner pada ketinggian 20.000 feet dengan luas penampang spinner (A), density udara $(\rho)$ pada lampiran dan drag coefficient $\left(C_{d}\right)$ untuk bentuk benda seperti spinner terdapat pada Gambar 2.40. rumus gaya tahanan fan blade:

$$
\begin{aligned}
S_{d}=\frac{1}{2} C_{d} \rho A & c_{o}^{2} \\
& \rho(\text { density udara })=0.5328 \frac{\mathrm{kg}}{\mathrm{m}^{3}} \\
& C_{d}=0.5 \\
& A(\text { luas penampang Spinner })=0.6715 \mathrm{~m}^{2} \\
& C_{0}=164,1 \mathrm{~m} / \mathrm{s}
\end{aligned}
$$

Jawab jadi harga tahanan spinner

$$
\begin{aligned}
& S_{d}=\frac{1}{2} C_{d} \rho A c_{o}^{2} \\
& S_{d}=\frac{1}{2} \times 0.5 \times 0.5328 \frac{\mathrm{kg}}{\mathrm{m}^{3}} 0.6715 \mathrm{~m}^{2} \mathrm{x} \\
& (164,1 \mathrm{~m} / \mathrm{s})^{2} \\
& S_{d}=\frac{1}{2} \times 0,179 \frac{\mathrm{kg}}{\mathrm{m}} \times 26928,8 \mathrm{~m}^{2} / \mathrm{s}^{2} \\
& S_{d}=2408,6 \mathrm{~N}
\end{aligned}
$$

Jadi gaya tahanan spinner pada ketinggian 10.000 feet adalah $2408,6 \mathrm{~N}$.

Maka gaya tahanan $\left(F_{D}\right)$ fan blade pada ketinggian 20.000 feet adalah

$$
\begin{aligned}
& F_{D}=F_{d}+S_{d} \\
& F_{D}=13556,65 \mathrm{~N}+2408,6 \mathrm{~N} \\
& F_{D}=15965,3 \mathrm{~N}
\end{aligned}
$$

\section{KESIMPULAN}

Hasil analisa aliran udara fan blade CFM 56 $-7 B$ dengan Computational Fluid Dynamic dapat disimpulkan sebagai berikut:

1. Velocity $\mathrm{x}$ dan pressure setelah melewati fan blade pada ketinggian 10.000 feet, masingmasing menghasilkan 157,057 m/s untuk velocity x lebih besar $30,082 \mathrm{~m} / \mathrm{s}$ dari input dan 64801.10 pa untuk pressure lebih kecil 2078,04 Pa dari input. Sedangkan berdasarkan ketinggian 20.000 feet, masing-masing menghasilkan $199,797 \mathrm{~m} / \mathrm{s}$ untuk velocity $\mathrm{x}$ lebih besar $35.697 \mathrm{~m} / \mathrm{s}$ dari input dan 30619,11 Pa untuk pressure lebih kecil 1786,25 Pa dari input.

2. Pola aliran udara yang dibelakang fan blade menghasilkan pola aliran udara laminar

3. Gaya dorong (trusth) yang di hasilkan pada ketinggian 10.000 feet adalah 115120,442 Newton dan pada ketinggian 20.000 feet adalah 134418,55 Newton.

4. Gaya tahanan (drag) yang di hasilkan pada ketinggian 10.000 feet adalah 12244,13 $\mathrm{N}$ dan pada ketinggian 20.000 feet adalah 15964,3 N.

\section{DAFTAR PUSTAKA}

Anderson, Jhon D, Jr. 1995. Computational Fluida Dynamic ( $2^{\text {nd }}$ ed). New York Mc Graw Hill.

Arismunandar, Wiranto. 2002, Pengantar Turbin Gas dan Motor Propulsi, Bandung: Penerbit ITB

Budiarso Harinaldi. 2015, Sistem Fluida, Jakarta: Penerbit Erlangga

CFMI Training Manual CFM 56 - 7B Basic Engine

Deny Bayu Saefudin, 2018. Kajian Kerupaan Parameter Kinerja Miniatur dan Prototipe Turbine Angin Sumbu Horizontal. Volume: 1

Heriyanto Rusmayardi, 2018. Model Perencanaan Performasi Aerodinamika Turbin AnginDarrieus Dengan Metode Multiple Streamtube. Volume: 9

https://id.wikipedia.org/wiki/Engine_CFM56, Di akses pada tanggal 10 agustus 2019 pukul 18.30 WIB

Suyitmadi, 2010. Analisis Peningkatan Efisensi Turbofan Dengan Pembakaran Tambahan Pada Ruang Antar Turbine. Volume: 12 Halaman

Waluyo, Moch. Slamet. 1996, Seri Teknik Penerbangan Aerodinamika, Yogyakarta: Penerbit Andi 